\title{
Restraining the Assessment or Collection of a Federal Tax
}

$\mathrm{T}$ AXES have not, as a general rule, in this country since its independence, nor in England before that time, been collected by regular judicial proceedings", said Mr. Justice Miller in Kelly v. Pittsburg." "The necessities of government, the nature of the duty to be performed and the customary usages of the people", continued the learned Justice, "have established a different procedure." In the field of federal taxation this different procedure, involving collection by summary administrative process first and discussion afterwards, has been buttressed by section 3224 of the Revised Statutes which provides: "No suit for the purpose of restraining the assessment or collection of any tax shall be maintained in any court."

With the tremendous increase in the activities of the Federal Government in late years, evidence of abuse of administrative process has found its way into the law reports. For example, cases have arisen in widely scattered parts of the country where, under the guise of collecting taxes, revenue officers have undertaken to enforce the criminal features of the National Prohibition law by levying penalties upon the basis of secret administrative findings without trial by jury or otherwise, and collecting such penalties by distraint. There have also been cases reported in which over-zealous officers have undertaken to distrain the property of a wife to collect taxes due from her husband. Despite the provisions of section 3224, the courts have given relief in the cases referred to ; and by recent legislation, Congress has made some Moatbitish innovations upon the customary usages of revenue officers. By the Revenue Act of 1924, a Board of Tax Appeals was created. By the Revenue Act of 1926, certain prohibitions are imposed on summary enforcement of income and estate taxes, including a prohibition on distraint during the pendency of an appeal to the Board of Tax Appeals. The Revenue Act of 1926 also provides for judicial review of decisions of the Board of Tax Appeals. It further provides that "notwithstanding the provisions of section 3224 of the Revised Statutes," a deficiency assessment "during the time such prohibition is in force, may be enjoined by a proceeding in the proper court."?

1 (1881) 104 U. S. 78, 26 L. Ed. 658.

2 Revenue Act of $1926, \S 274$ (a); U. U. Stats. at L. - U. S. Comp. Stats. (1926) $\$ 6336 \mathrm{t} / 3 \mathrm{zz}$ (1), 41 Fed. Stats. Ann. (Supp. No. 41) 52; see also, $\$ 308$ (a). 
Far-reaching as this recent legislation is, it is applicable only to income tax and estate tax cases and does not afford relief in all of those cases. Thus, there is no right of appeal to the Board of Tax Appeals from a jeopardy assessment unless the taxpayer gives an indemnity bond in a sum fixed by the local collector, and likewise, there is no right judicially to review a decision of the Board of Tax Appeals unless the taxpayer gives an indemnity bond in a sum fixed by the board. There have been cases where collectors have arbitrarily fixed prohibitive bonds and it is of course conceivable that the Board of Tax Appeals may do likewise. So the construction of section 3224 of the Revised Statutes is still of considerable practical importance.

Section 3224 of the Revised Statutes has been before the Supreme Court and the lower Federal Courts in a number of cases. These cases suggest several observations of a general character. In the first place, it would appear that section 3224 may not be read literally. Although in terms it relates to "any tax" and "any court", it has been held that the former phrase relates only to Federal taxes, ${ }^{8}$ while the latter obviously includes state as well as Federal Courts. While the section declares that no suit shall be maintained "for the purpose of restraining the assessment or collection of any tax", it has been held that the prohibition is too narrow to prevent an injunction suit "by stockholders against corporations to restrain the corporations from paying taxes alleged to be unconstitutional",4 or to prevent a court from instructing its receiver as to whether or not to pay a tax levied by the Treasury ; ${ }^{5}$ but it is broad enough to prohibit a suit to set aside the sale of taxpayers' property made by the taxing authorities in enforcing summary collection. ${ }^{6}$ In the second place, section 3224 has been held to prohibit injunctions to restrain illegal taxes as

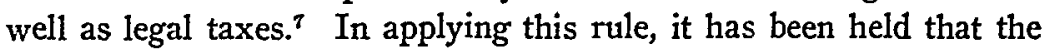
courts will not go behind the acts of the taxing officers charged with general jurisdiction of the subject when done under color of office. ${ }^{8}$ In the third place, section 3224 has been held not to prevent an

"Hill v. Wallace et al. (1922) 259 U. S. 44, 62, 66 L. Ed. 822, 42 Sup. Ct. Rep. 453.

"Graham v. Dupont (1923) 262 U. S. 234, 257-258, 67 L. Ed. 965, 43 Sup. Ct. Rep. 567 , citing cases.

$"$ Scott v. Ry. Co. (1917) 246 Fed. 545, 158 C. C. A. 515.

- Gouge v. Hart (1917) 250 Fed. 802, appeal dismissed (1920) 251 U. S. 542, 64 L. Ed. 405, 40 Sup. Ct. Rep. 583. 157.

"Snyder v. Marks (1883) 109 U. S. 189, 27 L. Ed. 901, 3 Sup. Ct. Rep.

${ }^{8}$ Nichols v. Gaston (1922) 281 Fed. 67, "If the plaintiff is within a class of persons against whom the Commissioner may make assessments, though his proceedings be ever so irregular and erroneous, the court cannot interfere." Kissinger v. Bean (1878) 7 Biss. 60, 14 Fed. Cas. No. 7853. 
injunction against impositions which by their very nature are penalties even though called taxes in the statute under which the levy is made. ${ }^{9}$ In the fourth place, it has been held that section 3224 does not prevent an injunction "in a case apparently within its terms in which some extraordinary and entirely exceptional circumstances make its provisions inapplicable." 10

We shall deal principally with cases of the third and fourth of these classes, and incidentally with cases of the second class.

In Lipke v. Lederer, ${ }^{11}$ the Supreme Court was called upon to determine whether section 3224 was applicable to certain impositions made under the National Prohibition Act. The bill alleged that Lipke, the plaintiff, having paid all internal revenue taxes required by the laws of the United States, had been arrested for selling liquor contrary to the National Prohibition Act, and had given bail to appear and answer; that while the prosecution was pending he received written notice that a tax had been assessed against him under the National Prohibition Act and demand for immediate payment, and that later he received a further notice that unless payment was made within ten days, the collector would make seizure and sale of his property. Plaintiff's contention was that the demand upon him was not for taxes, but for a penalty for an alleged criminal act, and that the method adopted for enforcing this penalty was contrary to the Federal Constitution, while defendant maintained "that the case involves only questions of construction; that section 3224, Revised Statutes, prohibits the relief prayed; that the bill states no ground for equitable relief; that full, adequate and complete remedy may be had at law." The district court dismissed the bill and plaintiff appealed to the Supreme Court. In reversing the case and holding plaintiff was entitled to an injunction, the Supreme Court held that in determining whether the imposition was a tax, it would look beyond the designation of it in the statute, saying:

"The mere use of the word 'tax' in an act primarily designed to define and suppress crime is not enough to show that, within the true intendment of the term, a tax was laid. When by its very nature the imposition is a penalty, it must be so regarded."'12

The court further held that section 3224 of the Revised Statutes did not apply, saying:

${ }^{9}$ Cases cited, infra.

10 Cases cited, infra.

11 (1922) 259 U. S. 557, 66 L. Ed. 1061, 42 Sup. Ct. Rep. 549.

12259 U. S. $557,561-562$. 
"The collector demanded payment of a penalty, and section 3224 , which prohibits suits to restrain the assessment or collection of any tax, is without application. And the same is true as to statutes granting the right to sue for taxes paid under protest. A revenue officer, without notice, has undertaken to assess a penalty for an alleged criminal act, and threatens to enforce payment by seizure and sale of property without opportunity for a hearing of any kind."13

On the question of due process, the court said:

"Before collection of taxes levied by statutes enacted in plain pursuance of the taxing power can be enforced, the taxpayer must be given fair opportunity for hearing-this is essential to due process of law. Central of Georgia R. Co. v. Wright, 207 U. S. $127,136,138,142,52$ L. Ed. 134, 141-143, 28 Sup. Ct. Rep. 47,12 Ann. Cas. 463. And certainly we cannot conclude, in the absence of language admitting of no other construction, that Congress intended that penalties for crime should be enforced through the secret findings and summary action of executive officers. The guaranties of due process of law and trial by jury are not to be forgotten or disregarded."14

Mr. Justice Brandeis, with whom Mr. Justice Pitney concurred, dissented because the bill failed "to allege any fact showing that the legal remedy would not be adequate, or that there was danger of irreparable injury."15

Regal Drug Corporation v. Wardell, ${ }^{18}$ which was decided at the next term of court involved the same questions as Lipke v. Lederer. The allegations in the Wardell case, showing plaintiff was entitled to equitable relief, were more comprehensive, it being alleged: "On the 19th day of July, 1920, the Commissioner took possession of complainant's drug store and of the entire stock of drugs therein, excluding complainant therefrom and is proceeding to, and threatening to sell the same in order to satisfy the so-called assessments of taxes and penalties, and that the damage done to complainant will be irreparable."17 The holding of the Circuit Court of Appeals for the Ninth Circuit, that the bill should be dismissed, was reversed without dissent on the part of any of the justices.

Is the rule announced in the Lederer and Wardell cases limited to suits involving penalties or is it of wider application?

13259 U. S. 557, 562.

1.259 U. S. $557,562$.

13259 U. S. 557, 563 .

13 (1922) 260 U. S. 386, 67 L. Ed. 318, 43 Sup. Ct. Rep. 152.

17260 U. S. $386,390$. 
Some of the cases decided under section 3224 throw light on this question.

In Frayers $v$. Russell, ${ }^{18}$ the court, on bill of review, upheld its prior action in granting a preliminary injunction, and later a perpetual injunction. The original bill alleged that complainants were engaged in manufacturing tobacco, and after selling a certain quantity, on which they had paid the stamp tax, defendant, as collector, informed thein he clained an additional tax of four cents per pound, amounting to the sum of $\$ 604.04$, and required and demanded payment of the same. In holding that the injunction was properly granted, the court said, in part:

"It is true that the collection of a tax by an officer of the government cannot be enjoined, and that all taxes due must be paid, and that the person paying them, when wrongfully levied, must resort to a suit against the collecting officer for the recovery of them. ... But in this case the proper tax had already been paid by the manufacturer, and he had sold and delivered the tobacco on which the tax was due. As to him the matter had been terminated, and he had passed from his ownership the tobacco which had been taxed. The collector's demand upon him afterwards for four cents a pound, which he called an additional tax, was a demand for what this court has solemnly and finally in another case adjudicated not to be a tax."

In Long $v$. Rasmussen, ${ }^{19}$ which was a suit in equity against a collector and another, plaintiff alleged that she owned and was entitled to the possession of certain property distrained by defendant collector, to make certain "distilled spirits taxes and penalties" assessed against one Wise. She sought to enjoin the threatened sale of her property and to recover possession thereof. In holding plaintiff was entitled to a decree, the court said :

"The suit is not against the United States, but is against an individual who, as an officer of the United States in discharge of a discretionless ministerial duty, upon plaintiff's property is committing without authority, contrary to his duty, and in violation of the due process of the Constitution and the revenue laws of the United States, positive acts of trespass for which he is personally liable. [Citing cases.] Congress has no power to grant, and has not assumed to grant, authority to the defendant collector to distrain the property of one person to make the taxes of another."20

18 (1878) 3 Hughes 227, 9 Fed. Cas. No. 5067 (Cir. Ct. E. D. Va.).

19 (1922) 281 Fed. 236 (D. C., D. Mont.).

20281 Fed. 236, 237-238. 
Referring to section 3224 of Revised Statutes, the court said: "It is a shield for official action, not a sword for private aggression."21

In Lafayette Worsted Company v. Page, ${ }^{22}$ the case arose out of a jeopardy assessment under the Revenue Act of 1924. Plaintiff had appealed to the Board of Tax Appeals but the Commissioner of Internal Revenue disregarded the appeal claiming the board had no jurisdiction. When the appeal was filed, the Commissioner "was threatening to enforce collection by immediate distraint." The board had decided in favor of its jurisdiction in similar cases. In granting a preliminary injunction against the collector, the court said:

"It can hardly be that the Commissioner is the sole and final judge of his own jurisdiction as between himself and an independent supervisory tribunal established by statute, nor that he is at liberty to disregard explicit provisions of law curtailing his power. ... The act of 1924 is basic. It affects not only the Commissioner's authority, but his power and jurisdiction."23

In connection with these cases, it may be observed that the Supreme Court has repeatedly held, in cases not involving the construction of section 3224, that it will not treat an unlawful charge as a tax: even though it is called a tax or is sought to be imposed under the guise of taxation. ${ }^{24}$

21281 Fed. 236, 238.

22 (1925) 6 Fed. (2d) 399 (D. C. R. I.).

23 Compare, Joseph Ganneau Co. v. Bowers (1925) 8 Fed. (2d) 379 (S. D. N. Y.). In Kissinger v. Bean, Fed. Cas. No. 7853, it was said: "I should not be prepared to hold that if the Commissioner were to determine that a person not a distiller and not interested in the business of distilling was subjest to an assessment as a distiller, that he was then within his juriscliction, and that a court of equity could not, because of the prohibition in Section 3224, intervene."

21 In U. S. v. B. \& O. R. R. Co. (1873) 84 U. S. 322,21 L. Ed. 596, it was held that bonds belonging to a municipal corporation could not be taxed under the Federal Income Tax Law of 1862 by requiring the debtor to withhold interest at the source, the court saying: "A tax is understood to be a charge, a pecuniary burden, for the support of Government. Of all burdens imposed upon mankind, that of grinding taxation is the most cruel. It is not taxation that Government should take from one the profits and gains of another. That is taxation which compels one to pay for the support of the Government from his own gains and of his own property." In Norwood v. Baker (1898) 172 U. S. 269, 278-279, 43 L. Ed. 443, 19 Sup. Ct. Rep. 187, it was said: "But the power of the legislature in these matters is not unlimited. - . In our judgment the exaction from the owner of private property of the cost of a public improvement in substantial excess of the special benefits accruing to him, is, to the extent of such excess, a taking, under the guise of taxation, of private property for public use withotit compensation." In Union Refrigerator Transit Co. v. Ky. (1905) 199 U. S. 194, 202, 50 L. Ed. 150, 26 Sup. Ct. Rep. 36, it was held that due process of law was denied a Kentucky corporation by a tax upon its rolling stock permanently located in other states. Referring to the assessment in question the court said: "The taxation of such property within the domicil of the 
Further light is thrown on the construction of section 3224, by cases decided under the Eleventh Amendment and state statutes similar to section 3224 .

The Eleventh Amendment is in the following words: "The Judicial power of the United States shall not be construed to extend to any suit in law or equity, commenced or prosecuted against one of the United States by Citizens of another State, or by Citizens or Subjects of any Foreign State." The cases hold that the amendment does not prevent an injunction against a state officer, "to restrain the seizure of property in the collection of taxes imposed in contravention of the Constitution of the United States." In Ex parte Tyler, the Supreme Court said:

"It has been repeatedly and uniformly held by this court that in a proper case for equity interposition, an injunction will lie to restrain the seizure of property in the collection of taxes imposed in contravention of the Constitution of the United States. [Citing cases] ... Where a suit is brought against defendants who claim to act as officers of a state, and, under color of an unconstitutional statute, commit acts of wrong and injury to the property of the plaintiff, to recover money or property in their hands unlawfully taken by them in behalf of the state, or for compensation for damages, or, in a proper case, for an injunction to prevent such wrong and injury, or for a mandamus in a like case to enforce the performance of a plain legal duty. purely ministerial, such suit is not, within the meaning of the amendment, an action against the state. *** The circuit courts of the United States will restrain a state officer from executing an unconstitutional statute of the state, when to execute it would be to violate rights and privileges of the complainant that had been guaranteed by the Constitution, and would do irreparable damage and injury to him." 25

Georgia has had statutory provisions similar to section 3224 for over a century, and there is a line of cases in that state construing the

owner partakes rather of the nature of an extortion than a tax, and has been repeatedly held by this court to be beyond the power of the legislature, and a taking of property without due process of law." In Hill v. Wallace (1921) 259 U. S. 44, 67-8, 66 L. Ed. 822, 42 Sup. Ct. Rep. 453, the court in holding the Future Trading Act unconstitutional quoted the following from the Child Labor Case: "Grant the validity of this law, and all that Congress would need to do hereafter, in seeking to take over to its control any one of the great number of subjects of public interest, jurisdiction of which the states have never parted with, and which are reserved to them by the tenth amendment, would be to enact a detailed measure of complete regulation of the subject, and enforce it by so-called tax upon departures from it. To give such magic to the word 'tax' would be to break down all constitutional limitation of the powers of Congress, and completely wipe out the sovereignty of the states."

25 (1893) 149 U. S. 164, 166, 37 L. Ed. 689, 13 Sup. Ct. Rep. 792. 
local statutes. In Wright, Comptroller-General, et al. v. Railroad Company, the court dealt with the construction of section 3668 of the Georgia code which declared: "No replevin shall lie nor any judicial interference be had in any levy or distress for taxes under the provisions of this Code, but the party injured shall be left to his proper remedy in any court of law having jurisdiction thereof." In the case cited the court said, quoting from and commenting on an earlier case:

" 'It is certain that as a general rule judicial interference with the collection of state taxes is forbidden. [Citing authorities.] Perhaps there is not, save in instances expressly provided for by the statute, a single real exception to the rule, properly understood, the sorcalled exceptions being only apparent. Nothing is a tax but what has the nature of a tax, and is imposed by some law. For an officer to exact money under the name of a tax, when there is no law to warrant the exaction, is not an attempt to collect taxes, but an attempt to collect something else; and the rule which excludes interference in the collection of taxes does not apply.' And the court goes on and applies this test: 'Conceding all the elements of fact to be as the officer decides them to be, or as favorable to him as possible, would his action be legal or illegal? If legal, no interference; if illegal, interference to the extent necessary for the citizen's protection'."20

In considering the applicability of the Georgia case and the Eleventh Amendment case in construing section 3224, as well as the other cases reviewed above, it might be well to glance at several recent cases in the Supreme Court dealing with the review of administrative proceedings.

In New York v. McCall et al., in passing upon a decision of the New York Public Service Commission, the Supreme Court said that it would "enter upon such an examination of the record as may be necessary to determine whether $* * *$ there was such a want of hearing or such arbitrary or capricious action on the part of the Commission as to violate the due process clause of the Constitution."27

In Keller v. Potomac etc. Company, the Supreme Court in speaking of the jurisdiction of the Federal Courts to review administrative proceedings under section 207 of the Judicial Code, said:

"This permits these courts to consider all relevant questions of constitutional power or right and all pertinent questions, whether the administrative order is within the statutory author-

26 (1880) 64 Ga. 783, 791. See also Le Roy v. City Ry. (1869) 18 Mich. 233.

27 (1917) 245 U. S. 345, 470, 62 L. Ed. 337, 39 Sup. Ct. Rep. 122. 
ity, or is an attempted exercise of it so unreasonable as not to be within it; but these are questions of law only. Interstate Commerce Commission v. Illinois C. R. Company, 215 U. S. 452, 54 L. Ed. 280, 287, 30 Sup. Ct. Rep. 155 . Of course, the consideration and decision of questions of law may involve a consideration of controverted facts to determine what the question of law is; but it is settled that any finding of fact by the commission, if supported by evidence, is final and conclusive on the courts."28

In Silberschein v. United States, in holding that the allegations in the petition did not present a case justifying judicial review of a decision of the director of the Veterans' Bureau, the Supreme Court said :

"The statute which creates the asserted right commits to the director of the Bureau the duty and authority of administering its provisions and deciding all questions arising under it; and in the light of the prior decisions of this court, we must hold that his decision of such questions is final and conclusive, and not subject to judicial review ; at least, unless the decision is wholly unsupported by the evidence, or is wholly dependent upon a question of law, or is seen to be clearly arbitrary or capricious." 29

Considering the several cases reviewed above together with the fact that the inhibitions of section 3224 are expressly directed against "restraining the assessment or collection of taxes", why should those inhibitions be applied to restraining anything but taxes? And where the contemplated action of the taxing officers is wholly unsupported by the evidence, or is wholly dependent upon a question of law erroneously decided by them, or is clearly arbitrary and capricious, why should section 3224 be held to prevent injunctive relief in an appropriate case?

Let us turn now to the question whether or not section 3224 prevents an injunction in cases apparently within its terms where there are extraordinary and exceptional circumstances.

Before examining the cases, it may be noted that independently of statute, the courts decline to enjoin the collection of a tax on the ground that it is illegal or unconstitutional unless in addition the bill and proofs bring the case under a recognized head of equity jurisdiction, such as fraud or the prevention of irreparable injury. ${ }^{30}$

The proposition as to exceptional circumstances seems to have been first noticed by the Supreme Court in Dodge v. Osborn. ${ }^{31}$ In

28 (1923) 261 U. S. 428, 442, 67 L. Ed. 731, 43 Sup. Ct. Rep. 445.

29 (1924) 266 U. S. 221, 225, 69 L. Ed. 256, 45 Sup. Ct. Rep. 69. 653.

30 Skelton v. Platt (1891) 139 U. S. 591, 35 L. Ed. 273, 11 Sup. Ct. Rep.

31 (1916) 240 U. S. 119, 60 L. Ed. 557, 36 Sup. Ct. Rep. 275. 
that case the suit was to enjoin the assessment and collection of income taxes. It was charged in the bill that the income tax section of the tariff act of October 3, 1913, was unconstitutional. Plaintiff's contention was that section 3224 was not applicable because there were "additional equities sufficient to sustain jurisdiction, wholly independent of the claim of unconstitutionality of the tax." 32 In disposing of this contention, and affirming a decree dismissing the bill, White, C. J., speaking for the full court, with the exception of McReynolds, J., who took no part in the case, said:

"Conceding for argument's sake only the legal premise upon which the contention rests, we think the conclusion that this case falls within such exception is wholly without merit, since, after an examination of the complaint, we are of the opinion that no ground for equitable jurisdiction is alleged. It is true the complaint contains averments that unless the taxes are enjoined many suits by other persons will be brought for the recovery of the taxes paid by them, and also that by reason of section 3187 , Rev. Stat. (Comp. Stat. 1913, section 5909), making the tax a lien on plaintiffs' property, the assessment of the taxes would constitute a cloud on plaintiff's title. But these allegations are wholly inadequate under the hypotheses which we have assumed solely for the sake of the argument, to sustain jurisdiction, since it is apparent on their face they allege no ground for equitable relief independent of the mere complaint that the tax is illegal and unconstitutional and should not be enforced-allegations which, if recognized as a basis for equitable jurisdiction, would take every case where a tax was assailed because of its unconstitutionality out of the provisions of the statute, and thus render it nugatory, while it is obvious that the statute plainly forbids the enjoining of a tax unless by some extraordinary and entirely exceptional circumstance its provisions are not applicable." ${ }^{3}$

Dodge v. Brady, ${ }^{34}$ is the next case in the reports following Dodge v. Osborn, supra. The appellants in the Brady case were the same as those in the Osborn case and the situation presented was substantially the same as in the previous case except that it was alleged "Plaintiffs had filed with the collector 'an appeal or claim for the remission and abatement of the surtaxes' because of the unconstitutionality of the statute imposing them, and that the Commissioner of Internal Revenue, to whom the claim had been forwarded by the collector had such protest under advisement." A supplemental bill, filed on the same day that the application was made for a preliminary

32240 U. S. 118, 121.

33240 U. S. $118,121-122$.

34 (1916) 240 U. S. 122, 60 L. Ed. 560, 36 Sup. Ct. Rep. 277. 
injunction, alleged that "since the filing of the original bill, the Commissioner of Internal Revenue had ruled adversely upon plaintiffs' protest, and that thereupon they [plaintiffs] had paid the surtaxes to the collector under protest and they prayed a recovery of the amount paid to the collector and for the other relief asked in the original bill. The defendant moved to dismiss the bill for want of jurisdiction because the suit was brought to enjoin the collection of a $\operatorname{tax} * * *$ and for want of equity because the income tax law was constitutional and valid. The court sustained the motion on the latter ground and dismissed the bill on the merits." The case went to the Supreme Court on direct appeal "because of the constitutional questions." In affirming the judgment, White, C. J., speaking for the whole court, with the exception of McReynolds, J., who took no part in the case, said:

"And it is argued by the government that there was no jurisdiction under the supplemental bill, since it fails to allege that an appeal was taken to the Commissioner of Internal Revenue after the payment of the taxes, and that he refused to refund them, and therefore fails to allege a compliance with the conditions imposed by sections 3220 and 3226 of the Revised Statutes (Comp. Stat. 1913, sections 5944, 5949), as prerequisites to a suit to recover taxes wrongfully collected. But, broadly considering the whole situation, and taking into view the peculiar facts of the case, the protest to the Commissioner, and his exertion of authority over it, and his adverse ruling upon the merits of the tax, thereby passing upon every question which he would be called upon to decide on an appeal for a refunding of the taxes paid, we think that this case is so exceptional in character as not to justify us in holding that reversible error was committed by the court below in passing upon the case upon its merits, thus putting an end to further absolutely useless and unnecessary controversy. We say useless and unnecessary because on the merits all the contentions urged by the appellants concerning the unconstitutionality of the law and of the surtaxes which it imposes have been considered and adversely disposed of in Brushaber v. Union P. R. Co. 240 U. S. 1, ante, 493, 36 Sup. Ct. Rep. 236."35

In Bailey v. George, ${ }^{36}$ the case went to the Supreme Court on appeal from the District Court for the Western District of North Carolina, to review a decree enjoining the collector of internal revenue from proceeding to enforce the Child Labor Tax Law. The case was reversed and remanded, with directions to dismiss the bill. The

35240 U. S. 122, 125-126.

36 (1922) 259 U. S. 16, 66 L. Ed. 816, 42 Sup. Ct. Rep. 419. 
opinion was by Taft, C. J., who spoke for the full court. In stating the facts in the case, the Chief Justice said:

"The decree $* * *$ recited that the complainants operated a manufacturing plant for the production of cotton goods $* * *$ that the defendant was a Federal collector of internal revenue; that, on the ground that the complainants had eniployed children in the factory within the limits of ages prescribed in *** the Child Labor Tax Law *** they were, under its terms, assessed the sum of $\$ 2,098.06$; that they filed a claim for abatement of the same, which was denied; that the collector was about to make the exaction by distraining complainants' property." ${ }^{37}$

In holding that the bill was without equity, and not within the exceptions to section 3224 of the Revised Statutes, the court said:

"An examination of the bill shows no other ground for equitable relief than as stated in the order. The bill does aver 'that these, your petitioners, have exhausted all legal remedies, and it is necessary for them to be given equitable relief in the premises'; but there are no specific facts set forth sustaining this mere legal conclusion. Sec. 3224, Rev. Stat., Comp. Stat. section 5947, 3 Fed. Stat. Anno. 2d ed. p. 1032, provides that 'no suit for the purpose of restraining the assessment or collection of any tax shall be maintained in any court.' The averment that a taxing statute is unconstitutional does not take this case out of the section. There must be some extraordinary and exceptional circumstance not here averred or shown to make the provisions of the section inapplicable. Dodge v. Brady, 240 U. S. 122, 126, 60 L. Ed. 560, 562, 36 Sup. Ct. Rep. 277. In spite of their averment, the complainants did not exhaust all their legal remedies. They might have paid the amount assessed under protest, and then brought suit against the collector to recover the amount paid, with interest. No fact is alleged which would prevent them from availing themselves of this form of remedy."'s8

In Hill v. Wallace et al. ${ }^{39}$ the case went to the Supreme Court on appeal from the District Court for the Northern District of Illinois. The bill sought an injunction against the Collector of Internal Revenue for the First Illinois District and others, in connection with taxes and penalties imposed under the Future Trading Act. A decree dismissing the bill was reversed and the cause remanded with instructions to issue the injunction. The bill was filed by members of the Board of Trade of Chicago against the Secretary of Agriculture, the Commissioner of Internal Revenue, the United States District

"2 259 U. S. 16, 19.

$3 n$ Ibid.

3" Supra, n. 3. 
Attorney for the Northern District of Illinois, the Collector of Internal Revenue for the First District of that state, the Board of Trade of the City of Chicago, its president, vice-president, and directors. The bill prayed for an injunction against all the defendants, including a prayer "to enjoin the Commissioner of Internal Revenue, the Collector of Internal Revenue, and the District Attorney, named as parties, from attempting to collect by suits, or prosecutions, or otherwise, any tax, penalty, or fine under the act." ${ }^{40}$ The jurisdiction of the district court was expressly challenged by the collector. On this point the opinion says :

"The Umited States attorney for the northern district of Illinois, and the Collector of Internal Revenue, moved the court to dismiss on the grounds that the suit was to restrain the collection of a tax, contrary to section 3224 of the Revised Statutes; and that the bill sought to restrain the enforcement of a criminal statute without showing that the complainants suffered irreparable injury." 41

The Future Trading Act imposed a tax of twenty cents a bushel on contracts for the sale of grain for future delivery, but excepted from its application sales on boards of trade designated as contract markets by the Secretary of Agriculture. It was alleged in the bill that twenty cents a bushel exceeded the average commissions of members of the board on grain over a long period of time, and that to acquire the status of a contract market it was necessary to admit to membership on the board representatives of co-operative associations of producers; and that to do so would involve deprivation of property without due process. Taft, C. J., speaking for the full court, opened his opinion with the following: "The first question for our consideration is whether, assuming the act to be invalid, the complainants, on the face of their bill, state sufficient equitable grounds to justify granting the relief they ask."42 After holding that the bill showed equitable grounds against the Board of Trade, its president and directors, the opinion proceeds :

"A further question arises as to whether this is a suit for an injunction against the collection of the tax, in violation of section 3224 Rev. Stat., Comp. Stat., section 5947, 3 Fed. Stat. Anno. 2d ed. p. 1032, in so far as it seeks relief against the District Attorney and Collector of Internal Revenue. Were this a state act, 
injunction would certainly issue against such officers, [citing cases.]"43

The opinion continues:

"Does section 3224, Rev. Stat. prevent the application of similar principles to a Federal taxing act? It has been held by this court, in Dodge v. Brady, 240 U. S. 122, 126, 60 L. Ed. 560, 562,36 Sup. Ct. Rep. 277, that section 3224 of the Revised Statutes does not prevent an injunction in a case apparently within its terms in which some extraordinary and entirely exceptional circumstances make its provisions inapplicable. See also Dodge v. Osborn, 240 U. S. 118, 122, 60 L. Ed. 557, 560, 36 Sup. Ct. Rep. 275. In the case before us, a sale of grain for future delivery without paying the tax, will subject one to heavy criminal penalties. To pay the heavy tax on each of many daily transactions which occur in the ordinary business of a member of the exchange, and then sue to recover it back, would necessitate a multiplicity of suits, and, indeed would be impracticable. For the Board of Trade to refuse to apply for designation as a contract market, in order to test the validity of the act, would stop its 1600 members in a branch of their business most important to themselves and to the country. We think these exceptional and extraordinary circumstances with respect to the operation of this act make section 3224 inapplicable." 44

The court then analyzed the Future Trading Act, held it unconstitutional, and explicitly ordered an injunction in the following words:

"The injunction against the Board of Trade and its officers, and the injunction against the Collector of Internal Revenue and the District Attorney, should be granted so far as section 4 is concerned and the regulations of the act interwoven within it. $* * *$ The decree of the District Court is reversed, and the cause is remanded-for further proceedings in conformity to this opinion." 15

Graham v. Dupont, went to the Supreme Court on a writ of certiorari to the Circuit Court of Appeals for the Third Circuit. The District Court for Delaware had made its order temporarily restraining the collector from levying a distraint to collect a tax. The only ground on which equitable relief was sought was that if plaintiff paid the tax he would be precluded from filing a claim for refund by the statute of limitations. In reversing the case, Taft, C. J., speaking for the full court, said: ".... Certainly complaintant could not, by delay-

43259 U. S. $44,62$.

4259 U. S. $44,62$.

కs 259 U. S. $44,72$.

16 Supra, n. 4. 
ing his payment until his right to sue to recover it back expires, make a case so extraordinary and entirely exceptional as to render section 3224, Revised Statutes, inapplicable." ${ }^{\text {"7 }}$ The Chief Justice also pointed out that the bar of the statute had been removed by subsequent legislation, saying:

"It is certain that, by the amendments to section 252 and section 3226 , Revised Statutes, $* * *$ the complainant is given the right now to pay the tax, and sue to recover it back, and, in such a suit, to raise the questions as to the value of the stock and the amount of the resulting tax, and also as to bar of time against the assessment which he attempted to raise in the bill." 48

In reviewing previous cases, the court said:

"The cases of Lipke v. Lederer, 259 U. S. 557, 66 L. Ed. 1061, 42 Sup. Ct. Rep. 549, and Regal Drug Corp. v. Wardell, decided December 11, 1922, (260 U. S. 386, ante, 318, 43 Sup. Ct. Rep. 152), were not cases of enjoining taxes at all. They were illegal penalties in the nature of punishment for a criminal offense. Pollock v. Farmers' Loan \& T. Co. 157 U. S. 429, 39 L. Ed. 759, 15 Sup. Ct. Rep. 673, and Brushaber v. Union P. R. Co., 240 U. S. 1, 60 L. Ed. 493, L. R. A. 1917D, 414, 36 Sup. Ct. Rep. 236, Ann. Cas. 1917B, 713, were suits by stockholders against corporations to restrain the corporations from paying taxes alleged to be unconstitutional. Hill v. Wallace, 259 U. S. 44, 66 L. Ed. 822,42 Sup. $C_{t}$. Rep. 453 , was in part a suit like the foregoing. It was a bill filed by members of the Chicago Board of Trade to prevent the governing board from applying to the Secretary of Agriculture to have the Board of Trade designated as a 'contract market' under the Future Trading Act, on the ground that the act was unconstitutional and its operations would impair the value of the Board to its members. Without such designation, no member could have sold grain for future delivery without paying a prohibitive tax; and, if he sold without paying the tax, he was subjected to heavy criminal penalties. To pay such a tax on each of the many thousands of transactions on the Board, and to sue to recover them back, would have been utterly impracticable. It would have blocked the entire future grain business of the country, and would have seriously injured not only the members of the Board, but also the producing and consuming public. This phase of the situation was so clear that the government in effect consented to the temporary injunction. See Hill v. Wallace, 257 U. S. 310, 66 L. Ed. 253, 42 Sup. St. Rep. 168, s. c. 257 U. S. 615,66 L. Ed. 398, 42 Sup. Ct. Rep. 96 . Under these extraordinary and most exceptional circumstances, it was held that section 3224 was not applicable to prevent an injunc- 
tion against collection of such a prohibitive tax, imposed for the purpose of regulating the future grain business, with all the unnecessary and disastrous consequences its enforcement would entail if the act was unconstitutional. Hill v. Wallace should, in fact, be classed with Lipke v. Lederer, supra, as a penalty in the form of a tax. Certainly we have no such case here." $\$$

It will be observed in considering these cases that the points actually decided are all consistent with one another, and it may well be doubted whether in the cases in which relief was denied the decisions cannot be accounted for on ordinary equitable principles without reference to section 3224.

Dodge v. Osborn only held that where an injunction is sought against a tax assessed under an alleged unconstitutional statute which by its terms makes the tax a lien on the taxpayer's property, equitable jurisdiction cannot be conferred by the mere allegation that unless an injunction were granted, other persons as well as the plaintiff would bring suits for the recovery of taxes paid under the statute. In Dodge v. Brady was not the question of jurisdiction a moot question? The point decided in Bailey v. George was that where plaintiff is able to pay the tax assessed and sue to recover the same, he has an adequate remedy at law and may not go into equity on the sole ground of the alleged unconstitutionality of the statute. In Hill v. Wallace, in addition to the allegations of unconstitutionality, it was alleged that the payment of the tax would be impracticable and the enforcement of the statute would result in grave public inconvenience. The Dupont case held no more than that a taxpayer able to pay an alleged unconstitutional tax who stands by and permits the statute of limitations to run, is not entitled to relief in equity, especially where Congress has removed the bar of the statute.

The statement in the Dupont case that the Wallace case "should, in fact, be classed with Lipke v. Lederer, supra, as a penalty in the form of a tax" has been thought to impair the Wallace case as an authority. Now the Lederer case and the Wallace case were decided at the same term of court, the latter case having been decided first. The Lederer case held that section 3224 was by its terms not applicable to an imposition called a tax by Congress which was in fact not a tax but a penalty. In the Wallace case as in the Lederer case, the court had to consider first, the question of jurisdiction, and secondly, the merits. In each case both questions were decided in favor of the plaintiff therein. In discussing the jurisdictional question in the

19262 U. S. $234,257-258$. 
Wallace case, the imposition sought to be enjoined is spoken of as a tax, although it is held unconstitutional when the merits are reached. In the Wallace case, the decision on the jurisdictional question was not put on the ground that the imposition was not a tax, but on the ground "that section 3224 of the Revised Statutes does not prevent an injunction in a case apparently within its terms in which some extraordinary and entirely exceptional circumstances make its provisions inapplicable." May an imposition called a tax by Congress not be said to be "apparently within" the "terms" of section 3224, but not actually so if declared not to be a tax, whether on constitutional or other grounds? And may not the finding that such imposition is not a tax together with special grounds for relief be said to constitute "some extraordinary and entirely exceptional circumstances" that make the terms of the section "inapplicable"?

Whether or not the Dupont case indicates a change in the trend of decision is not for us to say. We may venture to suggest, however, that if the inhibitions of section 3224 are applicable only to restraining the assessment or collection of taxes, using the word taxes in its true sense, and if the determination of Congress or administrative officers, as to what are taxes is reviewable, then the scope of an independent doctrine built on exceptional circumstances may turn out to be somewhat narrower than might have been supposed.

Los Angeles, California.

Joseph L. Lewinson. 